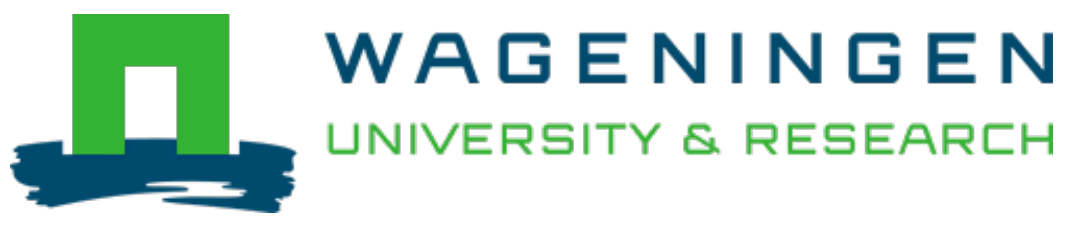

\title{
Fermentative preservation of plant foods
}

Journal of Applied Bacteriology

Nout, M.J.R.; Rombouts, F.M.

https://doi.org/10.1111/j.1365-2672.1992.tb03633.x

This publication is made publicly available in the institutional repository of Wageningen University and Research, under the terms of article $25 \mathrm{fa}$ of the Dutch Copyright Act, also known as the Amendment Taverne. This has been done with explicit consent by the author.

Article $25 \mathrm{fa}$ states that the author of a short scientific work funded either wholly or partially by Dutch public funds is entitled to make that work publicly available for no consideration following a reasonable period of time after the work was first published, provided that clear reference is made to the source of the first publication of the work.

This publication is distributed under The Association of Universities in the Netherlands (VSNU) 'Article $25 \mathrm{fa}$ implementation' project. In this project research outputs of researchers employed by Dutch Universities that comply with the legal requirements of Article $25 \mathrm{fa}$ of the Dutch Copyright Act are distributed online and free of cost or other barriers in institutional repositories. Research outputs are distributed six months after their first online publication in the original published version and with proper attribution to the source of the original publication.

You are permitted to download and use the publication for personal purposes. All rights remain with the author(s) and / or copyright owner(s) of this work. Any use of the publication or parts of it other than authorised under article $25 \mathrm{fa}$ of the Dutch Copyright act is prohibited. Wageningen University \& Research and the author(s) of this publication shall not be held responsible or liable for any damages resulting from your (re)use of this publication.

For questions regarding the public availability of this publication please contact openscience.library@,wur.nl 


\section{Fermentative preservation of plant foods}

\section{M.J.R. Nout and F.M. Rombouts}

Department of Food Science, Agricultural University, Wageningen, The Netherlands

1. Introduction, $136 \mathrm{~S}$

2. Driving force, $136 \mathrm{~S}$

2.1 Carbon, $136 \mathrm{~S}$

2.2 Nitrogen, $138 \mathrm{~S}$

2.3 Minerals, $138 \mathrm{~S}$

3. Epiphytic flora, $138 \mathrm{~S}$

4. Process conditions, $139 \mathrm{~S}$

4.1 (An)aerobiosis, 139S

4.2 Salts, $140 \mathrm{~S}$

4.3 Water, $140 \mathrm{~S}$

4.4 Temperature, $140 \mathrm{~S}$

4.5 Inhibitors, $140 \mathrm{~S}$
5. Natural fermentation, $141 \mathrm{~S}$

6. 'Controlled' natural fermentation, $141 \mathrm{~S}$

7. Pure culture fermentation, $141 S$

8. Impact, $142 \mathrm{~S}$

8.1 Anti-microbial metabolites of low molecular weight $(<1000), 142 \mathrm{~S}$

8.2 Anti-microbial products of molecular weight $\geqslant 1000,144 \mathrm{~S}$

8.3 Competition, $145 \mathrm{~S}$

9. Post-fermentation processing, $145 \mathrm{~S}$

10. Prospects, $145 S$

11. References, $145 \mathrm{~S}$

\section{INTRODUCTION}

Fermentation is an ancient method of food processing aimed at the prolongation of shelf-life and improvement of palatability. It may also improve digestibility and the nutritional value of food and feed. This article focusses mainly on the ecological aspects of fermentation for prolongation of shelf-life.

Fermented foods of plant origin are derived from a variety of raw materials of different chemical composition and biophysical properties (Table 1). Tuberous roots such as potatoes, cereals and tree-crops like breadfruit have a relatively high starch content. Legumes and oil seeds generally have a high protein content. Green vegetables, carrot, beet, tomato, olive, cucumber, okra and forage crops for animal feed silages have a high moisture content. Fruits contain high concentrations of reducing sugars. The preservation by fermentation of vegetables and cereals is mostly due to the action of lactic acid bacteria, often in combination with yeasts. However, other bacteria, e.g. Bacillus spp. or filamentous fungi, e.g. Rhizopus and Aspergillus spp. are equally important in the fermentation of legumes and oil seeds.

The economic importance of fermentative preservation is significant. For instance, in the USA approx. 300000 tonnes of cucumbers (Humphries \& Fleming 1989) and 200000 tonnes of cabbage (Stamer 1988) are fermented annually; in The Netherlands millions of tonnes of forage crops are ensiled annually, whereas in tropical countries a

Correspondence to: Dr M.J.R. Nout, Department of Food Science, Agricultural Cnizersity, Wageningen, The Netherlands. variety of fermented plant foods are considered to be essential dietary items.

\section{DRIVING FORCE}

Each type of raw material possesses a unique combination of physical structure, chemical composition and natural microflora which influences the sequence of microbial development (Andersson et al. 1988a) and the activity of endogenous enzymes of the raw material during fermentation. The availability of fermentable substrate is the most important driving force for fermentation. In this section, sources of carbon and nitrogen, as well as the availability of minerals will be discussed.

\subsection{Carbon}

Cereal grains and their milled derivatives contain only $0 \cdot 5-$ $2.5 \%$ of freely available carbohydrates, mainly mono- and disaccharides (Becker \& Hanners 1991). In raw (un-heated) cereals, however, starch and other polysaccharides may be mobilized by endogenous hydrolases, e.g. $\alpha$ - and $\beta$ amylases (Odunfa \& Adeyele 1987). Figure 1 illustrates such auto-amylolysis taking place in maize and sorghum. Generation of such fermentable carbohydrates is of particular importance in lactic acid fermentations, as most lactic acid bacteria lack the ability to degrade starch and show only limited activity in pre-cooked cereals. There are exceptions, e.g. Lactobacillus amylovorus, which can adhere to and degrade cooked starch granules. The addition of lytic enzymes of malted cereals to cooked starch results in a 
Table 1 Approximate chemical composition of plant foods (per $100 \mathrm{~g}$ edible portion)*

\begin{tabular}{lcccccc}
\hline & Roots & Cereals & Legumes & Oil seeds & Vegetables & Sugary fruits \\
\hline Moisture (g) & $50-80$ & $8-13$ & 12 & $3-6$ & $85-95$ & $85-91$ \\
Crude protein (g) & $0 \cdot 2-2$ & $5-14$ & $20-35$ & $15-30$ & $0 \cdot 5-5$ & $0 \cdot 5-1 \cdot 5$ \\
Crude fat (g) & $<0 \cdot 4$ & $1-5$ & $1-2$ & $35-65$ & $<1$ & $<2$ \\
Carbohydrates (g) & $17-37$ & $62-80$ & $40-60$ & $10-35$ & $1-6$ & $5-25$ \\
Reducing sugars (g) & $-\dagger$ & $0 \cdot 5-2 \cdot 5$ & $2-4$ & $5-10$ & $1-4$ & $5-20$ \\
Calcium (mg) & $7-150$ & $10-350$ & $30-300$ & $20-500$ & $10-150$ & $10-40$ \\
Phosphorus (mg) & 60 & $90-400$ & 400 & $90-600$ & $10-100$ & $8-50$ \\
Iron (m) & $0 \cdot 5-2$ & $0 \cdot 5-5$ & $5-10$ & $1-10$ & $0 \cdot 5-5$ & $0 \cdot 2-2$ \\
Sodium (mg) & 10 & $5-10$ & $2-10$ & $2-25$ & $5-100$ & $<5$ \\
Potassium (mg) & 600 & $100-400$ & $1000-1250$ & $400-900$ & $250-700$ & $75-300$ \\
Manganese (mg) & - & - & - & $500-800$ & $500-800$ & - \\
Vitamin A (I.U.) & $0-100$ & - & $0-100$ & $0-100$ & - & 00 \\
$\beta$-carotene (mg) & - & - & $0-0 \cdot 15$ & - & $0-2000$ \\
Thiamine (mg) & $0 \cdot 08-0 \cdot 15$ & $0 \cdot 10-0 \cdot 60$ & $0 \cdot 10-0 \cdot 9$ & $0 \cdot 03-1 \cdot 0$ & $0 \cdot 02-0 \cdot 15$ & $0 \cdot 02-0 \cdot 1$ \\
Riboflavin (mg) & $0-0 \cdot 06$ & $0 \cdot 05-0 \cdot 15$ & $0 \cdot 10-0 \cdot 4$ & $0 \cdot 01-0 \cdot 30$ & $0 \cdot 03-0 \cdot 30$ & $0 \cdot 02-0 \cdot 1$ \\
Niacin (mg) & $0 \cdot 30-1 \cdot 0$ & $0 \cdot 10-0 \cdot 35$ & $0 \cdot 25-0 \cdot 35$ & $0 \cdot 6-7$ & $0 \cdot 02-0 \cdot 25$ & $0 \cdot 2-2$ \\
Ascorbic acid (mg) & $0-20$ & - & - & $<10$ & $10-100$ & $5-150$ \\
\hline
\end{tabular}

* Compiled from multiple literature sources.

$\dagger$ No data available.

significant improvement of the growth and acidification by lactic acid bacteria. Alternatively, starch-degrading yeasts (Khetarpaul \& Chauhan 1990) or Bacillus spp. (Njoku \& Okemadu 1989) may be used to generate reducing sugars.

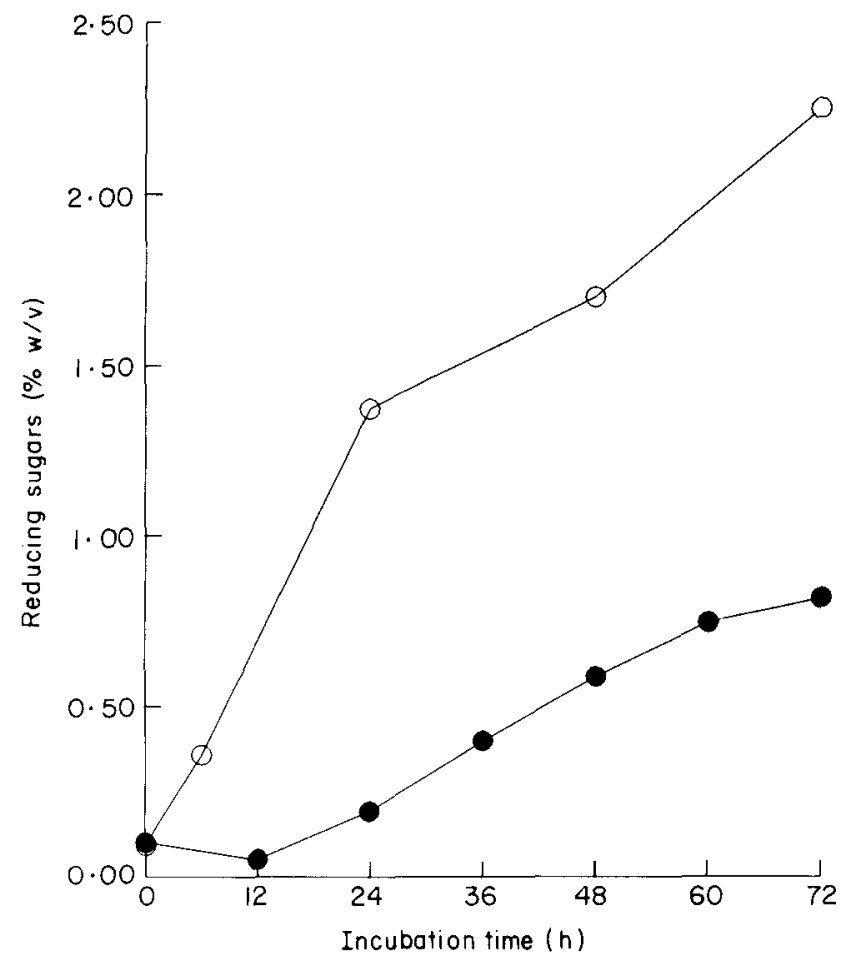

Fig. 1 Auto-amylolysis in cereals (based on data of Nout (1980) and Odunfa \& Adeyele (1987)). O, Maize; 9 , sorghum
In vegetables the sugar content is sufficiently high to support fermentative processes. Fresh vegetables contain mainly fructose, glucose and saccharose, in total approx. $1-4 \%$ (Table 1), depending on the degree of maturity. Other sources of carbon include pectic substances and organic acids. A variety of fungi and bacteria have pectolytic activity; from a food quality point of view, however, the degradation of pectic substances and subsequent loss of firmness is regarded as undesirable. Organic acids, particularly malic acid, can be assimilated, e.g. by Lact. plantarum; in cucumbers this may lead to undesirable accumulation of $\mathrm{CO}_{2}$. In the presence of citrate, Lact. plantarum can also degrade lactic acid to form acetic acid (Lindgren et al. 1990). Extraction of the fermentable matter from the plant cell may be achieved by physical disruption of the cellular structure, or by applying an osmotic gradient. In grass silage, physical disruption without salting is adequate. In some grasses the concentration of water-soluble carbohydrates is as high as $18 \%$, so that diffusion ceases to be a limiting factor (Heron et al. 1988). The extraction of fermentable sugars from vegetables by osmotic gradient is limited by diffusion rates. In cabbage and other leafy vegetables, shredding is combined with the application of 1-2\% salt $(\mathrm{NaCl})$, but in whole cucumbers, olives, onions, and carrots, $4-18 \%$ salt is required to achieve adequate extraction of fermentable sugars (Fleming 1991). In legumes, oil seeds and sugary fruits the availability of fermentable matter is not limiting, and can be achieved by soaking or crushing. 
Table 2 Epiphytic microflora on plant foods $(\log N / g)$

\begin{tabular}{|c|c|c|c|c|}
\hline & Roots & Cereals & $\begin{array}{l}\text { Legumes } \\
\text { and } \\
\text { oil seeds }\end{array}$ & Vegetables \\
\hline \multicolumn{5}{|l|}{ Bacteria } \\
\hline total aerobic & $4-6$ & $4 \cdot 5$ & $5-7 \cdot 7$ & +6 \\
\hline Enterobacteriaceae & $1 \cdot 7$ & $3 \cdot 5-5$ & $3 \cdot 5$ & $3-3 \cdot 5$ \\
\hline lactic acid bacteria & 2.7 & $2 \cdot 6-4 \cdot 3$ & $4 \cdot 2$ & $0 \cdot 7.4$ \\
\hline Yeasts and moulds & $2 \cdot 4$ & $2 \cdot 5-3 \cdot 2$ & $2 \cdot 5$ & $0 \cdot 3-4 \cdot 6$ \\
\hline
\end{tabular}

Compiled from multiple literature sources.

\subsection{Nitrogen}

Although most plant materials contain enough organic nitrogen to support fermentation, its availability may be limited by protein- or $\alpha$-amino-complexing substances, e.g. phytic acid and phenolic compounds. Degradation of the latter, combined with proteinase and peptidase activity, increases the level of free amino acids and $\mathrm{NH}_{3}$ nitrogen (Njoku \& Okemadu 1989). Poolman \& Konings (1988) concluded that the rate of active transport of amino acids into the cell of (dairy) lactococci is not a limiting factor for growth at $\mathrm{pH}$ values below 7 (see Marshall, this Symposium, pp. 127S-135S).

\subsection{Minerals}

Microbial activity is regulated by mineral availability. Mineral ions of metabolic importance include $\mathrm{Ca}^{2+}, \mathrm{Fe}^{2+}$, $\mathrm{K}^{+}, \mathrm{Mg}^{2+}, \mathrm{Mn}^{2+}, \mathrm{Na}^{+}, \mathrm{P}^{3+}$ and $\mathrm{Zn}^{2+}$. Naturallyoccurring phytic acid chelates minerals and reduces their availability. Degradation by microbial or endogenous phytase increases $\mathrm{Ca}^{2+}, \mathrm{Cu}^{2+}, \mathrm{Fe}^{2+}, \mathrm{Mg}^{2+}, \mathrm{P}^{3+}$ and $\mathrm{Zn}^{2+}$ availability. Calcium is involved in the ethanol tolerance of Saccharomyces cerevisiae; $\mathrm{Fe}^{2+}$ is generally required for bacterial growth, except by lactic acid bacteria; $\mathrm{Mn}^{2+}$ is part of the defence against endogenous $\mathrm{O}_{2}^{-}$in plantassociated Lactobacillus, Pediococcus and Leuconostoc spp. (Daeschel et al. 1987); and $\mathrm{Zn}^{2+}$ stimulates $\alpha$-amino $\mathrm{N}$ assimilation.

\section{EPIPHYTIC MICROFLORA}

Many foods of plant origin are fermented without prior heat treatment. Consequently, the epiphytic microflora found on the raw material (Table 2) is present at the start of the fermentation.

Strictly aerobic epiphytic bacteria include Bacillus, Flavobacterium spp., Pseudomonadaceae and moulds. Facultative anaerobes of importance are the Enterobacteriaceae, lactic acid bacteria and yeasts.

Microbial properties including energy metabolism, lag time, maximum specific growth rate and ability to adhere

Table 3 Major lactic acid bacteria in naturally fermented products of plant origin

\begin{tabular}{|c|c|c|c|c|c|c|c|c|c|c|c|c|c|c|}
\hline \multirow{2}{*}{$\begin{array}{l}\text { Obligate homofermentative } \\
\text { Enterococius faccium }\end{array}$} & \multicolumn{4}{|c|}{$\begin{array}{l}\text { Recorded } \\
\text { occurrence }\end{array}$} & \multirow[t]{2}{*}{$\begin{array}{l}\text { Facultative } \\
\text { heterofermentative }\end{array}$} & \multicolumn{4}{|c|}{$\begin{array}{l}\text { Recorded } \\
\text { occurrence }\end{array}$} & \multirow[t]{2}{*}{$\begin{array}{l}\text { Obligate } \\
\text { heterofermentative }\end{array}$} & \multicolumn{4}{|c|}{$\begin{array}{l}\text { Recorded } \\
\text { occurrence }\end{array}$} \\
\hline & & 2 & & 4 & & & & & & & & & & \\
\hline Lactobacilus acidophilus & 1 & 2 & & & & & & & & & & & & \\
\hline \multirow[t]{5}{*}{ lactis } & 1 & 2 & & & & & & & & Lactobacillus brevis & 1 & 2 & 3 & \\
\hline & & & & & Lactobacillus bavaricus & 1 & & & & brevis var. lindneri II & & 2 & & \\
\hline & & & & & casei & 1 & 2 & & 4 & büchneri & & 2 & & \\
\hline & & & & & coryniformis & & 2 & & & cellobiosus & 1 & 2 & 3 & \\
\hline & & & & & curvatus & 1 & & & & confusus & 1 & 2 & & \\
\hline delbrückü ssp. delbrücku & & 2 & & & & & & & & coprophilus & & & 3 & 4 \\
\hline delbrückii ssp. lactis & & & 3 & & & & & & & fermentum & 1 & 2 & & \\
\hline \multirow[t]{3}{*}{ leichmannii } & 1 & & & & & & & & & sanfrancisco & & 2 & & \\
\hline & & & & & & & & & & Leuconostoc dextranicum & 1 & 2 & & \\
\hline & & & & & plantarum & 1 & 2 & 3 & 4 & mesenteroides & 1 & 2 & 3 & \\
\hline salivarius & 1 & & & & saké & 1 & & & & paramesenteroides & 1 & 2 & & \\
\hline Streptococcus spp. & & & 3 & 4 & & & & & & & & & & \\
\hline botis & & 2 & & & & & & & & & & & & \\
\hline Enteracocus faecals: & 1 & 2 & & & & & & & & & & & & \\
\hline Streptocacus thermophilus & 1 & & & & & & & & & & & & & \\
\hline Pediocoicus acidilacici & 1 & 2 & & & & & & & & & & & & \\
\hline damnosus & 1 & 2 & & & & & & & & & & & & \\
\hline pentosaceus & 1 & 2 & 3 & & & & & & & & & & & \\
\hline
\end{tabular}

Occurrence: 1 , vegetables; 2 , cereals; 3 , root crops $; 4$, oil seeds and legumes.

Compiled from multiple literature sources. 
Table 4 Major yeasts in naturally fermented products of plant origin

\begin{tabular}{|c|c|c|}
\hline Species & & corded in \\
\hline \multicolumn{3}{|l|}{ Fermentative } \\
\hline Candida famata & & 2 \\
\hline guilliermondii & 1 & 2 \\
\hline lambica & & 2 \\
\hline krusei & & 2 \\
\hline milleri & & 2 \\
\hline sake & 1 & \\
\hline Hansenula sp. & 1 & \\
\hline anomala & & 2 \\
\hline Saccharomyces sp. & 1 & 2 \\
\hline cerevisiae & & 2 \\
\hline dairensis & & 2 \\
\hline exiguus & & 2 \\
\hline Torulaspora delbrückii & & 2 \\
\hline Torulopsis sp. & 1 & \\
\hline holmii & & 2 \\
\hline \multicolumn{3}{|l|}{ Oxidative } \\
\hline Aureobasidium spp. & 1 & 2 \\
\hline Candida sp. & 1 & 2 \\
\hline curvata & & 2 \\
\hline Cryptococcus spp. & 1 & 2 \\
\hline Debaryomyces sp. & 1 & \\
\hline Geotrichum candidum & 1 & 2 \\
\hline Pichia sp. & 1 & 2 \\
\hline Rhodotorula spp. & 1 & 2 \\
\hline rubra & & 2 \\
\hline glutinis & & 2 \\
\hline Sporobolomyces spp. & 1 & 2 \\
\hline Trichosporon beigelii & & 2 \\
\hline
\end{tabular}

Occurrence: 1 , vegetables $; 2$, cereals.

Compiled from multiple literature sources.

or penetrate into the substrate are important factors that influence the chance of domination in a mixed microflora. Particularly, members of the Enterobacteriaceae (Enterobacter and Klebsiella spp.) dominate the early stages of fermentation because of their high specific growth rates at neutral $\mathrm{pH}$. Their mixed acid metabolism results in acetic acid, formic acid and $\mathrm{CO}_{2}$ and they are inhibited at $\mathrm{pH}$ $\leqslant 5 \cdot 5$.

Table 3 summarizes the epiphytic lactic acid bacteria occurring in food plants. Obligate homofermentative species produce lactic acid from all assimilable carbohydrates while obligate heterofermentatives produce a range of products including lactic acid. Facultative heterofermentatives, e.g. Lact. plantarum ferment glucose homofermentatively, whereas other carbohydrates can be fermented in a heterofermentative manner. From a functional point of view, heterofermentative lactic acid bacteria contribute to flavour development. In low-salt fermentations Leuconostoc mesenteroides is usually one of the first lactic acid bacteria to dominate due to its short lag and generation times (Stamer 1988). In cucumber fermentations, lactic acid bacteria enter the plant tissue through fissures and stomata but yeast cells are too large to penetrate (Daeschel et al. 1987).

Table 4 lists yeasts that occur frequently in fermented foods. The majority of epiphytic yeasts (mainly Aureobasidium, Cryptococcus, Rhodotorula and Sporobolomyces spp.) do not ferment sugars (Dobolyi \& Kecskés 1990), but several can use pectins as a carbon source. In pickled vegetables especially, fermentative yeasts play a crucial role in preservation through removal of fermentable substrate. In contrast, oxidative yeasts are associated with spoilage by degradation of organic acids, which causes an increase in $\mathrm{pH}$ and growth of spoilage-causing, acid-sensitive organisms.

Even under sub-optimum nutritional conditions, adequate colonization of the substrate and consequently biological stabilization can take place if commensalism or protoco-operation is possible. In particular, the fastidious lactic acid bacteria benefit from the presence of yeasts and it has been hypothesized that the extent of acidification in cereal lactic fermentation is regulated by yeast growth (Nout 1991). Also, in sourdough, growth of maltose nonfermenting yeasts is enabled by maltose-fermenting lactobacilli which, in turn, are stimulated by yeast peptides (Sugihara 1985).

\section{PROCESS CONDITIONS}

Figure 2 summarizes the principles and major operations involved in fermentative production of representative groups of plant foods. Heating and size reduction affect the epiphytic flora and the availability of substrates. Environmental factors determining the microbial activity will be discussed below.

\section{1 (An)aerobiosis}

Anaerobic conditions are created by consumption of oxygen by plant and microbial respiration, while oxygen access is prevented either by submersion under gentle pressure (Andersson et al. 1988a), in soil-covered pits (Aalbersberg et al. 1988) or in anaerobic tanks flushed with nitrogen gas (Humphries \& Fleming 1989). The aim of anaerobiosis is to inhibit potential spoilage by acetic acid bacteria, oxidative yeasts including Candida spp. (Middelhoven \& Van Baalen 1988) and moulds. However, the complete absence of $\mathrm{O}_{2}$ is not always optimum, since it has been shown recently that in lactic acid fermentations with, e.g. Lact. fermentum 


\begin{tabular}{|c|c|c|c|c|c|c|c|c|}
\hline & Root crops & Cereals & & & Legumes & Vegetables & & \\
\hline \multirow{5}{*}{$\begin{array}{l}\text { Raw material } \\
\text { Preparatory }\end{array}$} & Cassava & Maize & Maize & Maize & Soya bean & Grass & Cabbage & Cucumber \\
\hline & Peel & Grain & Flour & Dry grits & Dehull & Cut & Trim & Wash \\
\hline & Wash & Soak & Soak & Cook & Soak & & & \\
\hline & Grate & Grind & & Cool & Decant & Chop & Shred & Tank \\
\hline & & & & & & Heap & & \\
\hline \multirow{4}{*}{ Salting } & $\ldots$ & - & - & - & - & - & Dry salt & Brine \\
\hline & & Sieve & & Add bran & Cook & & & (Acidify) \\
\hline & & Sediment & & & Cool & & & Purge \\
\hline & & & & & & & & Buffer \\
\hline \multirow{3}{*}{ Inoculation } & (Starter) & - & (Starter) & Starter & Starter & (Starter) & (Starter) & (Starter) \\
\hline & Pressurize & & & & Package & Pressurize & Pressurize & \\
\hline & & & & & & Cover & Cover & \\
\hline Fermentation & Ferment & Ferment & Ferment & Ferment & Ferment & Ferment & Ferment & Ferment \\
\hline Maturation & $\cdots$ & - & - & - & - & Store & Store & Store \\
\hline Processing & Roast/fry & Boil/steam & Boil/steam & - & Cook/fry & Airing & Pasteurize & Pasteurize \\
\hline Product & Gari & Ogi & Uji & Mageu & Tempe & Silage & Sauerkraut & Pickles \\
\hline
\end{tabular}

Fig. 2 Fermentative processing of representative plant foods. -, Not applied; ( ), optional

(Vahvaselkä et al. 1990), and in mixed olive fermentations subtle aeration improves the speed of the process and the quality of the product.

\subsection{Salts}

Sodium chloride applied either directly or as a brine serves multiple functions as a food ingredient, amongst which is the inhibition of micro-organisms. The antimicrobial action of $\mathrm{NaCl}$ comprises a non-specific $a_{w}$ reduction effect and an additional inhibitory effect. $\mathrm{NaCl}$ does not specifically inhibit spoilage or pathogenic organisms; lactic acid bacteria and yeasts are also inhibited. Leuconostoc spp. are the least salt-tolerant, whereas lactobacilli and pediococci have similar salt tolerance. For instance, in cucumbers the optimum salt concentration for lactic acid bacteria is $5 \%$; at this concentration, lactic acid bacteria dominate over yeasts and Enterobacter spp., whereas at higher salt levels $(10-16 \%)$ lactic acid bacteria are strongly inhibited and are, in turn, dominated by yeasts and Enterobacter spp. (Stamer 1988). Salt and acidity have cumulative inhibitory effects. For example, inhibition of Propionibacterium acnes in olive brines required $11 \%$ salt at $\mathrm{pH} 7 \cdot 0,9 \%$ at $\mathrm{pH} \mathbf{5} \cdot 1$ and no salt at $\mathrm{pH} 3.5$ (Fleming et al. 1989)

Reduction of salt consumption by reducing salt concentrations or by using salt substitutes in vegetable fermentations is of consumer health interest. In cucumber juice, $\mathrm{NaCl}$ and $\mathrm{KCl}$ were found to be more selective in favour of Lact. plantarum compared with $\mathrm{CaCl}_{2}$ and $\mathrm{MgCl}_{2}$; sulphates and phosphates were unsuitable (Naewbanij et al. 1986).

\subsection{Water}

The availability of water, expressed as water activity $\left(a_{\mathrm{w}}\right)$ or, more precisely from a thermodynamics point of view, water potential, is influenced by the total moisture content, the presence of hydrating substances including salts, proteins and sugars, and temperature. Xerotolerance and osmotolerance are governed by different mechanisms (Ushio \& Nakata 1989). The inhibitory effect of reduced $a_{w}$ interacts with $\mathrm{pH}$, atmospheric composition and temperature. Yeasts usually require less available water than lactic acid bacteria (Rehacek et al. 1982).

\subsection{Temperature}

Most fermentations of plant material take place at ambient temperatures. Exceptions are fermentations with thermophilic Bacillus spp. (Odunfa 1986) or Lact. delbrückii (Haggblade \& Holzapfel 1989) that take place at $45^{\circ}-55^{\circ} \mathrm{C}$. Seasonal or geographical temperature differences contribute to the dominating microflora in, e.g. sourdough, silages and sauerkraut. For example, Leuc. mesenteroides and the majority of yeasts are favoured at $20^{\circ}-30^{\circ} \mathrm{C}$, whereas most lactic acid bacteria grow more rapidly at $30^{\circ}-35^{\circ} \mathrm{C}$ (Andersson $e t$ al. 1988a). Although acidification has no sharp temperature optimum, higher temperatures tend to increase the rate of acidification. On the other hand, lower temperatures favour growth (Vahvaselkä \& Linko 1990) and may still achieve lower final $\mathrm{pH}$ and higher titratable acidity in the long run.

\subsection{Inhibitors}

Naturally- and widely-occurring substances, e.g. phytic acid and polyphenols (Niwa et al. 1987) inhibit growth by 


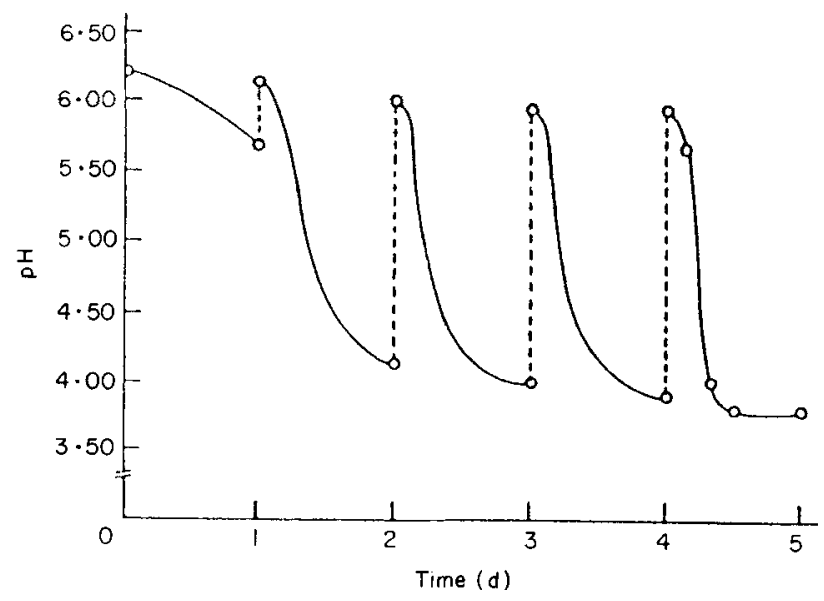

Fig. 3 Lactic fermentation of sorghum by daily back-slopping (inoculation rate $3 \%$; incubation at $30^{\circ} \mathrm{C}$ ) (Nout et al. 1988)

reducing the availability of minerals and/or nitrogenous substrates. Other natural inhibitors include phenolic (e.g. caffeic) acids, proteins, organic acids, essential oils, pigments and oleuropein, some of which are highly concentrated in spices, herbs, onion and garlic (Beuchat \& Golden 1989).

Chemical additives may be used to control fermentations. For example, nitrite can be used to inhibit lactobacilli and leuconostocs in pickles to produce a mildly acid product (Miyao \& Ogawa 1990); in silages, $\mathrm{Na-or} \mathrm{Ca-acrylate} \mathrm{can}$ be used to selectively inhibit heterofermentative lactic acid bacteria, and $\mathrm{Fe}$ (II)-scavengers, e.g. 2,2'-dipyridyl have been shown to suppress non-lactic acid bacteria (yeasts, clostridia and Enterobacteriaceae) (Bruyneel et al. 1990).

\section{NATURAL FERMENTATION}

Natural fermentations are initiated without the addition of micro-organisms and their control is limited to maintenance of external environmental conditions. A full microbial succession takes place. This has the advantage of developing complex ('rich') flavours but the drawback of being prone to off-flavours or failures. Natural vegetable fermentations undergo successive stages including an initiation phase dominated by Gram-positive and Gram-negative bacteria. Primary fermentation is dominated by lactic acid bacteria and yeasts. Subsequently, a secondary fermentation takes place during which residual fermentable sugars are depleted by fermentative yeasts. Spoilage flora, e.g. propionibacteria and clostridia, may develop at this stage and degrade lactic acid, especially if the $\mathrm{pH}$ is too high or the salt and acid concentrations are too low. Finally, a post-fermentation stage occurs, during which oxidative yeasts, moulds and bacteria can develop, especially in open storage vessels (Fleming 1991). Natural fermentations of cereals, roots and oil seeds undergo similar microbial successions. Tables 3 and 4 list the major lactic acid bacteria and yeasts involved in natural fermentations. Other micro-organisms of importance include Corynebacterium and Micrococcus spp. in, e.g. cassava and Bacillus, Pseudomonas and Staphylococcus spp. in oil seeds and legumes.

\section{6. 'CONTROLLED' NATURAL FERMENTATION}

In order to speed up the fermentation and increase its predictability, process control is required. Two principles should be distinguished, i.e. ecological vs environmental control.

Ecological control involves enrichment of starter organisms in the food by natural selection. 'Back-slopping', i.e. using inoculum from a previous batch of product, as is practised in sourdough, soyabean soaking for tempe manufacture (Nout \& Rombouts 1990) and lactic fermentations of cereal-legume mixtures (Nout 1991) results in highly competitive and well-adapted multiple strain starters. Figure 3 illustrates the favourable effect of 'back-slopping' on the effectiveness of sorghum acidification.

Environmental control involves choosing pretreatments and incubation conditions to ensure and maintain the artificial dominance of starter organisms over epiphytic microorganisms. The type of starter may vary from certain fermented foods, e.g. curdled milk or yoghurt (containing a variety of lactic acid bacteria, Enterobacteriaceae and yeasts), to more specific starters, e.g 'ragi' tablets (containing Amylomyces and Endomycopsis spp.) for tapé fermentation (Ardhana \& Fleet 1989), or 'usar' leaves (containing Rhizopus spp.) for tempe fermentation (Nout \& Rombouts 1990). Washing, cooking, disinfection, packaging and temperature control all contribute to process predictability.

\section{PURE CULTURE FERMENTATION}

Single or mixed cultures may be added to raw materials to achieve dominance over the epiphytic flora. This principle and practise are widely applied in, e.g. silages that use Lact. plantarum, Lact. brevis, Pediococcus acidilactici and Bacillus pumilus (Hendrick et al. 1991), and in vegetable fermentations (cabbage, carrots, cassava and okara). Pure cultures are selected according to criteria that include homo- or heterofermentation and $\mathrm{CO}_{2}$ production, rate of production of organic acids and their configurations, temperature range, flavour production, acid tolerance, salt tolerance and cell sedimentation. Mixed starters consisting of lactic acid bacteria and fermentative yeasts are quite successful in achieving biological stability by assimilating all available fermentable carbohydrates (Daeschel et al. 1988). 
Temporary dominance over the epiphytic microflora requires large inocula and supportive process control. Operations including washing, chlorination, exchange of internal gases with $\mathrm{O}_{2}$ (Andersson et al. 1988a), brine $\mathrm{pH}$ control by buffers, e.g. $\mathrm{Na}$ - or Ca-acetate to assist in 'full curing', purging of produced $\mathrm{CO}_{2}$, and the use of anaerobic tanks, all help to sustain the temporary dominance of the added starter culture (Fleming 1991). In silages, Lact. plantarum must be added at at least twice the level of the epiphytic Enterobacter cloacae (Bruyneel \& Verstraete 1986) or $10^{5}-10^{6} \mathrm{cfu} / \mathrm{g}$ (Heron et al. 1988). Excessive domination, however, may lead to flavour defects, e.g. when a pure culture of homofermentative Lact. bavaricus is used to enhance the $\mathrm{L}(+)$ lactic acid content in sauerkraut, the flavour-producing Leuc. mesenteroides cannot develop sufficiently. Figure 4 illustrates the effect of control measures in cucumber fermentation on the rate and extent of acid production, $\mathrm{pH}$ decrease, sugar utilization and $\mathrm{CO}_{2}$ production. Another approach to ensure dominance of starter cultures is to use organisms which produce antibiotics. Harris et al. (1990) suggested using a mixed culture for sauerkraut fermentation. This consisted of a nisin-resistant Leuc. mesenteroides and a nisin-producing Lactococcus lactis

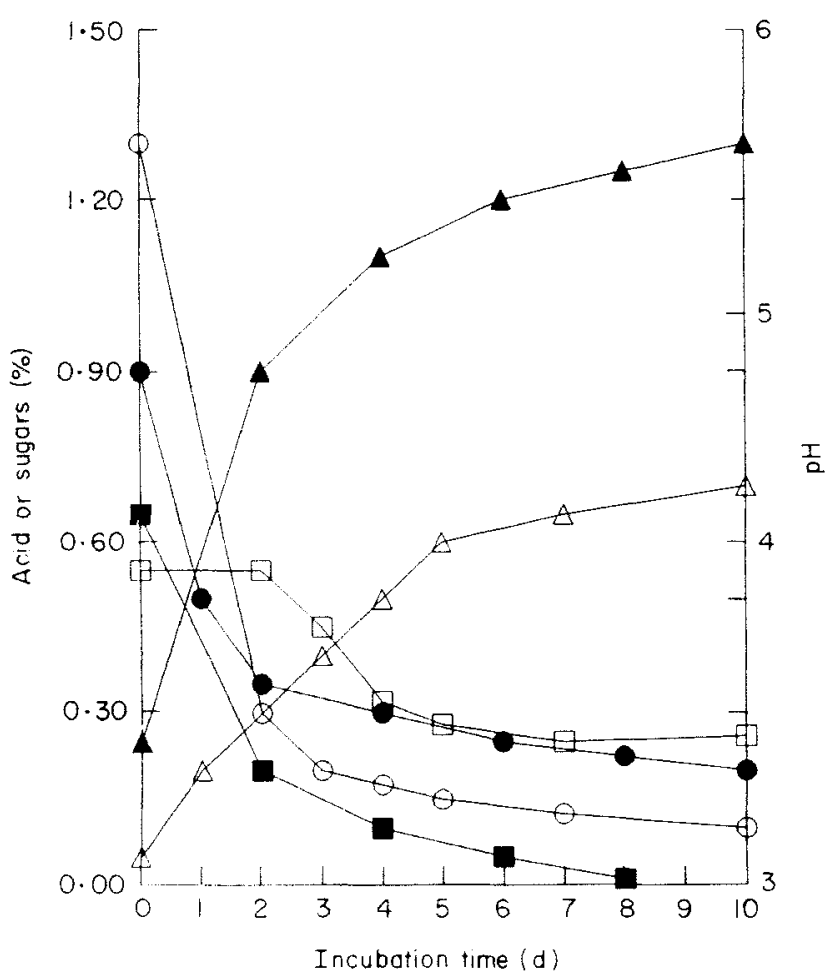

Fig. 4 Comparison of natural and controlled cucumber fermentation (based on data of Fleming (1984)). Open symbols, natural fermentation; closed symbols, controlled fermentation. $\bigcirc, \mathrm{pH} ; \square$, sugar; $\triangle$, acid to maintain dominance over the nisin-sensitive epiphytic Lact. plantarum.

To increase the effect of pure culture starters, fermentations of pasteurized or sterilized substrate under aseptic conditions are desirable. Fermentation of pasteurized vegetable juice using mixtures of heterolactic bacteria results in pronounced flavour development. Preconditioning of cucumbers followed by fermentation with malate decarboxylase-deficient mutants of Lact. plantarum has the advantage of reduced gaseous spoilage. However, many of the commercial large-scale fermentations cannot be carried out profitably under such conditions as they require expensive energy and equipment.

\section{IMPACT}

In addition to the environmental factors mentioned above, the preservative effect of fermentation is attributed to accumulation of antimicrobial products (Table 5), and to microbial competition.

\subsection{Anti-microbial metabolites of low molecular weight $(<1000)$}

Weak organic acids, particularly lactic and acetic acids, probably account for most of the inhibitory effect on a broad spectrum of micro-organisms. As the formation of organic acids takes place gradually, this leaves opportunities for acid-sensitive organisms, e.g. Enterobacteriaceae to multiply during early stages of the fermentation. The inhibitory effect of undissociated organic acids is $10-600$ times stronger than that of their dissociated molecules; the extent of dissociation is directly determined by the $\mathrm{pH}$. Undissociated citric and lactic acid have the highest toxicity, but acetic acid is the most effective in moderatelyacid products due to its high pK $(4 \cdot 75)$ value. Factors that affect the $\mathrm{pH}$ reduction in a product include the types and concentrations of lactic acid bacteria and fermentable carbohydrates, the rate of acid production and growth, the presence of inhibitory factors and the initial $\mathrm{pH}$ and buffering capacity of the food. The synergistic inhibitory effect of mixtures of lactic and acetic acids has been ascribed to the potentiation of acetic acid at the lower $\mathrm{pH}$ produced by lactic acid. The mechanism of inhibition studied in yeasts indicated that excessive energy is required to maintain the intracellular $\mathrm{pH}$ at the original level (Warth 1988) by continuous removal of protons and/or undissociated acid molecules; to this effect the cytoplasmic membrane must be intact (Shah \& Jelen 1990). The intracellular $\mathrm{pH}\left(\mathrm{pH}_{\mathrm{i}}\right)$ at which cellular functions are inhibited varies with species and is different for growth or acid production. The acid resistance of Lact. plantarum might be the result of the low 
Table 5 Antimicrobial products accumulating during fermentation

\begin{tabular}{|c|c|c|c|}
\hline Substance & Produced by & Active against & $\begin{array}{l}\text { Status of acceptance } \\
\text { as food ingredient }\end{array}$ \\
\hline \multicolumn{4}{|c|}{ Molecular weight $<1000$} \\
\hline \multicolumn{4}{|c|}{ Acids } \\
\hline lactic acid & All LAB & All micro-organisms & GRAS \\
\hline acetic acid & Het. LAB & $\begin{array}{l}\text { All micro-organisms, } \\
\text { pH-dependent }\end{array}$ & \\
\hline Alcohols & Yeasts & All micro-organisms & GRAS \\
\hline Carbon dioxide & Het. LAB & $\begin{array}{l}\text { Most micro-organisms } \\
\text { aqueous : at } \mathrm{pH} \geqslant 6 \\
\text { gas: at } 20-50 \%\end{array}$ & GRAS \\
\hline Diacetyl & Lactococcus spp. & $\begin{array}{l}\text { Yeasts, } G-\text { bact : at } 200 \mathrm{ppm} \\
\text { Non-LAB, G + : at } 300 \mathrm{ppm} \\
\quad \text { (butter flavour: } 2-4 \mathrm{ppm} \text { ) }\end{array}$ & GRAS \\
\hline Hydrogen peroxide & All LAB & All micro-organisms & $\begin{array}{l}\text { Not approved (USA) } \\
\text { as additive }\end{array}$ \\
\hline Microgard $^{R}$ & Propionibacterium shermanii & Most $\mathrm{G}-$, some yeasts & \\
\hline Reuterin & Lactobacillus reuteri & Broad: $G+, G-$, fungi & FDA-approved \\
\hline \multicolumn{4}{|c|}{ Bacteriocins (molecular weight $\geqslant 1000$ ) } \\
\hline Lactacin B & Lactobacillus acidophilus & LAB & \\
\hline Lactobacillin & brevis & LAB & \\
\hline Brevicin & brevis & LAB & \\
\hline Caseicin 80 & casei & Lactobacillus brevis & \\
\hline Bulgarican & delbrückii ssp. bulgaricus & Broad, incl. G- & \\
\hline N.N. & fermentum & Broad G+, incl. Listeria spp. & \\
\hline Lactocin 27 & helveticus & Broad G+, incl. Listeria spp. & \\
\hline Plantaricin A & plantarum & LAB & \\
\hline Nisin & Lactococcus lactis & $\begin{array}{l}\text { Broad G+, incl. Listeria spp. } \\
\quad \text { Bacillus, Clostridium spp. }\end{array}$ & GRAS \\
\hline Diplococcin & lactis ssp. cremoris & Narrow: Lactococcus lactis, Clostridium spp. & \\
\hline N.N. & Leuconostoc dextranicum & & \\
\hline N.N. & gelidum & LAB, Listeria spp. & \\
\hline Pediocin & Pediococcus acidilactici & Broad G+ & \\
\hline N.N. & pentosaceus & Broad G+ & \\
\hline
\end{tabular}

LAB, Lactic acid bacteria; Het, heterofermentative; GRAS, generally recognized as safe; G-, Gram-negative bacteria; G +, Grampositive bacteria; N.N., not named; FDA, United States Food and Drugs Administration.

$\mathrm{pH}_{\mathrm{i}}(4 \cdot 6)$ at which it is inhibited, compared with $5 \cdot 2$ for Lact. helveticus (Vahvaselkä \& Linko 1990) and $5 \cdot 4$ for Leuc. mesenteroides (McDonald et al. 1990). However, other mechanisms may also contribute to acid resistance. For example, at decreasing $\mathrm{pH}$, Lact. plantarum tends to produce acetoin, rather than lactic acid, from pyruvate. McFall \& Montville (1989) concluded that the ability to shift between the production of neutral (acetoin) and acidic (lactic acid) compounds may help Lact. plantarum to main- tain pH homeostasis; similarly, Vahvaselkä \& Linko (1990) found that lactate production by Lact. plantarum and Lact. helveticus was maximum at near-neutral $\mathrm{pH}(5 \cdot 4-5 \cdot 8)$. Acid production and growth of lactic acid bacteria are also directly influenced by $a_{w}$, and can be described by a nonlinear Arrhenius model (Larsen \& Anon 1989). Figure 5 illustrates the effect of water activity on the effectiveness of sorghum acidification by 'back-slopping'. At reduced $a_{w}$ (0.92) growth and acidification occur at a significantly 


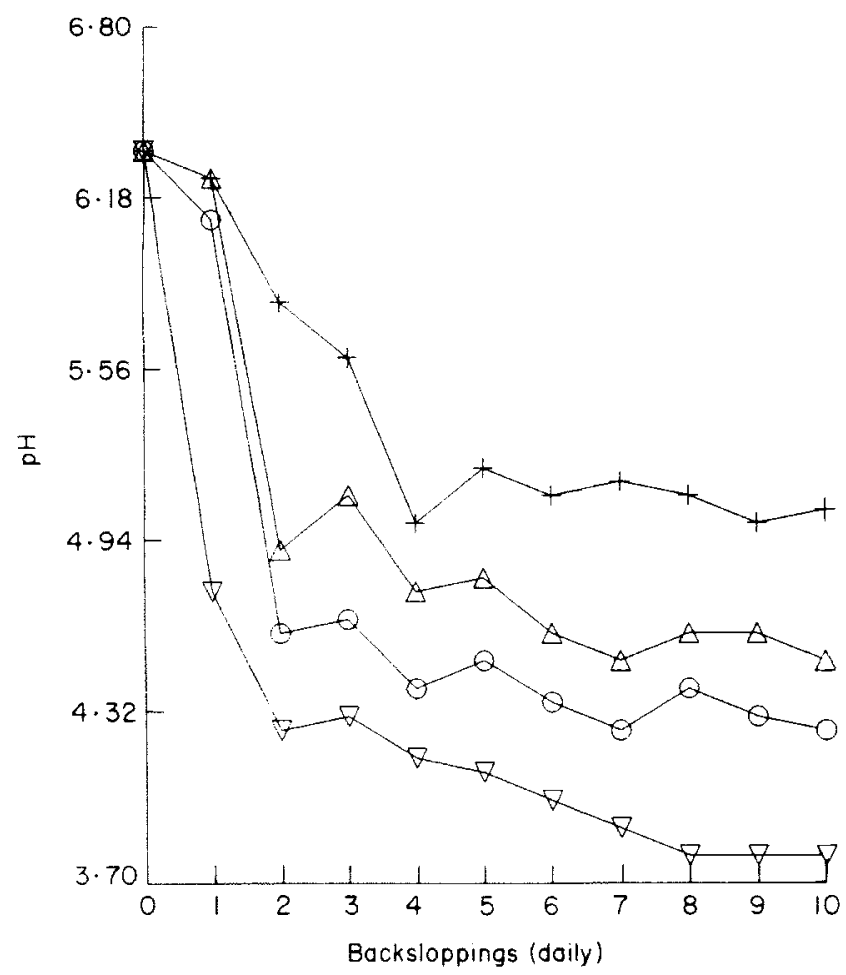

Fig. 5 Effect of water activity on sorghum acidification by daily back-slopping (Nout, unpublished). $a_{\mathrm{w}} ;+, 0.92 ; \triangle, 0.94 ; \bigcirc$, $0.96 ; \nabla, 0.99$

reduced rate since considerable energy is diverted towards maintenance.

The inhibitory effect of alcohols on yeasts is associated with the increase of the anion and proton permeability of the plasmalemma, e.g. in Sacch. carlsbergensis, resulting in a loss of $\Delta \mathrm{pH}\left(\mathrm{pH}_{\text {out }}-\mathrm{pH}_{\mathrm{in}}\right)$ and membrane potential. $\mathrm{C}_{6}$ alcohols have the stongest effect (Petrov \& Okorokov 1990). The permeabilization was reduced by the addition of $\mathrm{Mg}^{2+}$ or $\mathrm{Ca}^{2+}$. In general, large $(>10 \%)$ amounts of ethanol are required to achieve a significant preservative effect.

Considerable production of $\mathrm{CO}_{2}$ can take place as a result of heterofermentative degradation of hexoses and pentoses and also from decarboxylation of, e.g. malic acid. The dissolved $\mathrm{CO}_{2}$ is in equilibrium with $\mathrm{HCO}_{3}^{-}$to which the antimicrobial effect was ascribed by Daniels et al. (1985). At $\mathrm{pH} \leqslant 6$, however, only $2 \%$ of the aqueous $\mathrm{CO}_{2}$ is present as $\mathrm{HCO}_{3}^{-}$and consequently its antimicrobial effect in most fermentations should be negligible. In the gaseous phase, $2-5 \% \mathrm{CO}_{2}$ stimulates growth of lactic acid bacteria and fungi, whereas concentrations $>10 \%$ have a significant antimicrobial effect. Consequently, it may be expected that in hermetically-sealed conditions, $\mathrm{CO}_{2}$ accumulation contributes to preservation.

Diacetyl has a broad spectrum antimicrobial effect at concentrations of $300-1000 \mathrm{ppm}$ but, since it produces a marked butter flavour at $c a 5 \mathrm{ppm}$, its contribution to preservation is limited. The amount of $\mathrm{H}_{2} \mathrm{O}_{2}$ produced by lactic acid bacteria is variable and depends on the strain and availability of $\mathrm{O}_{2}$ (Gibbs 1987). There is no published evidence of its preservative effect in fermented plant foods. Several non-proteinaceous, antimicrobial substances of low molecular weight are reported, other than organic acids or $\mathrm{H}_{2} \mathrm{O}_{2}$. For example, reuterin, a non-proteinaceous metabolite of glycerol produced by Lact. reuteri, has a broadspectrum antimicrobial effect on Gram-negative and Gram-positive bacteria, yeasts and filamentous fungi.

\subsection{Anti-microbial products of molecular weight $\geqslant 1000$}

Strains of lactic acid bacteria, including Lactobacillus, Lactococcus, Pediococcus, Streptococcus and Leuconostoc spp., are able to excrete antimicrobial proteins (bacteriocins). The mechanism of the antimicrobial activity of most bacteriocins starts with a more or less specific adsorption on to the host cell wall. In resistant cells, no reaction takes place, but sensitive cells will be killed quickly. This bactericidal effect has been associated with leakage of ions and also with lysis (Andersson et al. 1988b).

The majority of proteinaceous bacteriocins are inactivated by proteolytic enzymes including pronase, ficin and some by trypsin. They resist cooking and are active over a wide range of $\mathrm{pH}$ (Bhunia et al. 1988). The ability of lactic acid bacteria to produce bacteriocins is receiving increasing attention as it could improve the competitiveness of starters. Fermentation starter strains could be selected according to their ability to produce bacteriocins; alternatively, recombinant DNA techniques could be used to equip conventional starter strains with bacteriocin production ability. The objective of such biopreservation systems would be to suppress epiphytic spoilage flora in situ, or to prepare a 'natural' antimicrobial additive, e.g. the Microgard ${ }^{R}$ system.

For about 60 years, nisin has been known to be particularly inhibitory to Gram-positive spore-forming bacteria. So far, this is the only bacteriocin that has been given Generally Recognised As Safe (GRAS) status and that is commercially used as an additive in processed cheese, canned vegetables, sterilized milk products and beer and wine fermentations (Radler 1990).

At present, commercial application of bacteriocins or bacteriocin-producing starters is limited. Because of their specificity, bacteriocins may not inhibit all undesirable micro-organisms (yeasts are seldom affected); instead they may even suppress desirable lactic acid bacteria. Also, their production in foods is less than in laboratory media. Bacteriocins may also be inactivated by food constituents and in solid foods their diffusion is limited. 


\subsection{Competition}

In addition to oxygen consumption and the consequent lowering of the redox potential, competition for nutrients contributes to the preservative impact of fermentations. For instance, in cucumber fermentations fermentative yeasts play an important role in preservation by competing for carbon sources. Sugar depletion by yeasts is maximum if very low $\mathrm{pH}$ values are avoided by using buffers ( $\mathrm{Na}$ - or Ca-acetate) or assimilation of glucose with simultaneous decarboxylation of L-malate by lactic acid bacteria (Daeschel 1988). Competition for carbon sources has also been demonstrated in fungal-fermented foods. Although the preservative effects of Bacillus spp. in silages (Hendrick et al. 1991) and fermented foods (Odunfa 1986) are as yet poorly understood, competition probably plays an important role.

\section{POST-FERMENTATION PROCESSING}

The biological stability of fully fermented material depends on the combined preservative effects of anaerobiosis, metabolites, salt (if any) and depletion of substrates. If a fermentation is interrupted or completed by changing any of these conditions, the integrity of the preservative mechanism is lost. This has been shown to trigger development of oxidative yeasts and lactate degradation in silage (Middelhoven \& Van Baalen 1988) followed by butyric spoilage and growth of acid-sensitive putrefactive autotrophs, e.g. Clostridium tertium (Fleming et al. 1989). Consequently, additional processing is required for shelf-life prolongation. This could involve, e.g. reduction of water activity by dehydration, or heating by baking, steaming or pasteurizing. An alternative to post-fermentation processing could be in-pack fermentation, such as practised with, e.g. sauerkraut and sorghum beer (Haggblade \& Holzapfel 1989).

\section{PROSPECTS}

In industrially-manufactured consumer goods, the ability to control fermentation processes through better understanding of the ecological keyfactors is of prime importance; also, the quality characteristics and stability of consumer products will increasingly benefit from the use of mutant or recombinant DNA strains designed, e.g. for reduced gas production, production of bacteriocins and novel flavours.

In animal feed preservation in silages, important issues for research will be the control of the microbial population and nutritional status of the product.

New ways should be found to suppress or inactivate clostridia in silage, as this leads to an increase in their numbers in milk and consequently, the higher incidence of butyric acid fermentation failures in cheese manufacture. Another problem is the widespread growth of Penicillium roqueforti in silage with possible formation of mycotoxins.

Fermented foods play an important role in the diet in tropical developing countries. Particularly, fermentation processes contribute to the microbiological and chemical safety of cereal and root crop products (Cooke et al. 1987). Traditional sour-fermented cereal products prevent the multiplication of pathogenic bacteria that are responsible for, e.g. diarrhoea, one of the major causative factors of child mortality. Controlled lactic fermentation can be employed to ensure adequate and predictable acidification, e.g. in the manufacture of weaning foods.

\section{REFERENCES}

Aalbersberg, W.G.L., Lovelace, C.E., Madhoji, K \& Parkinson, S.V. (1988) Davuke, the traditional Fijian method of pit preservation of staple carbohydrate foods. Ecology of Food and Nutrition 21, 173-180.

ANdersson, R.E., Daeschel,M.A. \& Eriksson, C.E. (1988a) Controlled lactic acid fermentation of vegetables. In Proceedings of the 8th International Biotechnology Symposium, Paris 1988. ed. Durand, G., Bobichon, L. \& Florent, J. pp. 855-868. Paris: Société Française de Microbiologie.

Andersson, R.E., Daeschel, M.A. \& Hassan, H.M. (1988b) Antibacterial activity of plantaricin SIK-83, a bacteriocin produced by Lactobacillus plantarum. Biochimie 70, 381390.

Ardhana, M.M. \& Fleet, G.H. (1989) The microbial ecology of tape ketan fermentation. International Journal of Food Microbiology 9, 157-165.

Becker, R. \& Hanners, G.D. (1991) Carbohydrate composition of cereal grains. In Handbook of Cereal Science and Technology ed. Lorenz, K.J. \& Kulp, K. pp. 469-496. New York: Marcel Dekker.

Beuchat, L.R. \& Golden, D.A. (1989) Antimicrobials occurring naturally in foods. Food Technology 43, 134-142.

Bhunia, A.K., Johnson, M.C. \& RAY, B. (1988) Purification, characterization and antimicrobial spectrum of a bacteriocin produced by Pediococcus acidilactici. Journal of Applied Bacteriology 65, 261-268.

Bruyneel, B.J., Van de Woestyne, M.M. \& VersTRAETE, W.H. (1990) Effect of 2,2'-Dipyridyl on silage fermentation. Journal of the Science of Food and Agriculture 51, 179-184.

Bruyneel, B. \& Verstraete, W. (1986) Influence of the inoculum size of Lactobacillus plantarum on the competition with Enterobacter cloacae. Biotechnology Letters 8, 629-634.

Cooke, R.D., Twiddy, D.R. \& Reilly, P.J.A. (1987) Lactic acid fermentation as a low-cost means of food preservation in tropical countries. FEMS Microbiology Reviems 46, 369-379.

DAESCHEL, M.A. (1988) A pH control system based on malate decarboxylation for the cultivation of lactic acid bacteria. Applied and Environmental Microbiology 54, 1627-1629. 
Daeschel, M.A., Andersson, R.E. \& Fleming, H.P. (1987) Microbial ecology of fermenting plant materials. FEMS Microbiology Reviems 46, 357-367.

Daeschel, M.A., Fleming, H.P. \& McFeeters, R.F. (1988) Mixed culture fermentation of cucumber juice with $\mathrm{Lac}$ tobacillus plantarum and yeasts. Journal of Food Science 53, 862864,888

Daniel.S, J.A., KRishnamurThi, R. \& Rizvi, S.S.H (1985) A review of effects of carbon dioxide on microbial growth and food quality. Journal of Food Protection 48, 532537.

Doвoly1, C. \& KeCsKÉs, M. (1990) Ecophysiological characteristics of the epiphytic yeast populations on some agricultural plants. Zentralblatt für Mikrobiologie 145, 334.

Fleming, H.P. (1984) Developments in cucumber fermentation. Journal of Chemical Technology and Biotechnology 34B, 241-252.

Fleming, H.P. (1991) Mixed cultures in vegetable fermentations. In Mixed Cultures in Biotechnology ed. Zeikus, J.G. \& Johnson, E.A. pp. 69-103. New York : McGraw-Hill.

Fleming, H.P., Daeschel, M.A., McFeeters, R.F. \& Pierson, M.D. (1989) Butyric acid spoilage of fermented cucumbers. Journal of Food Science 54, 636-639.

Gibis, P.A. (1987) Novel uses for lactic acid fermentation in food preservation. In Changing Perspectives in Applied Microbiology ed. Gutteridge, C.S. \& Norris, J.R. pp. 51S-58S. Journal of Applied Bacteriology, Symposium Supplement 63.

HaggBlade, S. \& Holzapfel, W.H. (1989) Industrialization of Africa's indigenous beer brewing. In Industrialization of Indigenous Fermented Foods ed. Steinkraus, K.H. pp. 191284. New York: Marcel Dekker.

Harris, L.J., Fleming, H.P. \& Klafnhammer, T.R (1990) Use of Leuconostoc mesenteroides and nisin-producing Lactococcus lactis strains as a paired starter culture system for sauerkraut. FEMS Microbiology Reviems 87, P100 Poster F11.

Hendrick, C.A., SMiley, B.K., Shelley, T.H. \& TOMES, N.J. (1991) Use of a plasmid DNA probe to monitor populations of Bacillus pumilus inoculant strains in hay. Applied and Environmental Microbiology 57, 686-693.

Heron, S.J.E., EDWards, R.A. \& MCDONAld, P. (1988) The effects of inoculation addition of glucose and mincing on fermentation and proteolysis in ryegrass ensiled in laboratory silos. Animal Feed Science and Technology 19, 85-96.

Humphries, E.G. \& Fleming, H.P. (1989) Anaerobic tanks for cucumber fermentation and storage. Journal of Agriculcural Engineering Research 44, 133-140.

Khftarpaul, N. \& Chauhan, B.M. (1990) Effect of fermentation by pure cultures of yeasts and lactobacilli on the available carbohydrate content of pearl millet. Food Chemistry 36, $287-293$.

I.ARSEN, R.F. \& ANON, M.C. (1989) Effect of water activity of milk on acid production by Streptococcus thermophilus and Lat hacillus bulgaricus. Journal of Food Science 54, 917-921.

I " GREN, S.F., AXEISSON, L.T. \& MCFEETERS, R.F. i990) Anaerobic L-lactate degradation by Lactobacillus plantarum. FEMS Microbiology Letters 66, 209-213.

MCDONaId, L.C., Fleming, H.P. \& HaSSan, H.M. (1990) Acid tolerance of Leuconostoc mesenteroides and Lacto- bacillus plantarum. Applied and Environmental Microbiology 56, 2120-2124

MCFall, S.M. \& Montville, T.J. (1989) pH-mediated regulation of pyruvate catabolism in Lactobacillus plantarum chemostat cultures. Journal of Industrial Microbiology 4, 335340 .

Middelhoven, W.J. \& van Baalen, A.H.M. (1988) Development of the yeast flora of whole-crop maize during ensiling and during subsequent aerobiosis. Journal of the Science of Food and Agriculture 42, 199-207.

Miyao, S. \& OGAwa, T. (1990) Effect of nitrite on destruction of bacteria related to fermented pickles. Journal of the Japanese Society of Food Science and Technology 37, 665-669.

NaewbaniJ, J.O., Stone, M.B. \& Fung, D.Y.C. (1986) Growth of Lactobacillus plantarum in cucumber extract containing various chloride salts. Journal of Food Science 51, 1257 1259,1275

Niwa, M., Matsuoka, M., Nakabayashi, A., Shinagawa, K., Tsuchida, F., Saltoh, Y. \& Katayama, H. (1987) Lactic acid fermentation of fruit juices by lactic acid bacteria. Chemie Mikrobiologie Technologie der Lebensmittel 11, 81-88.

NJoKU, H.O. \& OKEMADU, C.P. (1989) Biochemical changes during the natural fermentation of the African oil bean (Pentaclethra macrophylla) for the production of ugba. Journal of the Science of Food and Agriculture 49, 457-465.

Nout, M.J.R. (1980) Microbiological aspects of the traditional manufacture of Busaa, a Kenyan opaque maize beer. Chemie Mikrobiologie Technologie der Lebensmittel 6, 137-142.

NouT, M.J.R. (1991) Ecology of accelerated natural lactic fermentation of sorghum-based infant food formulas. International Journal of Food Microbiology 12, 217-224.

Nout, M.J.R., Hautvast, J.G.A.J., HaAR, F. van der Marks, W.E.W. \& Rombouts, F.M. (1988) Formulation and microbiological safety of cereal-based weaning foods. In Improving Young Child Feeding in Eastern and Southern Africa. Household Level Food Technology. Proceedings of a workshop held in Nairobi, Kenya, 12-16 October 1987. pp. 245-260. Ottawa: International Development Research Centre.

Nout, M.J.R. \& Rombouts, F.M. (1990) Recent developments in tempe research. Journal of Applied Bacteriology 69, $609-633$

Odunfa, S.A. (1986) Dawadawa. In Legume-based Fermented Foods ed. Reddy, N.R., Pierson, M.D. \& Salunkhe, D.K. pp. 173-189. Boca Raton: CRC Press.

Odunfa, S.A. A Adeyele, S. (1987) Sugar changes in fermenting sorghum during preparation of 'ogi-baba' gruel. Journal of Food ES Agriculture 1, 95-98.

Petrov, V.V. \& OKorokov, L.A. (1990) Increase of the anion and proton permeability of Saccharomyces carlsbergensis plasmalemma by $n$-alcohols as a possible cause of its deenergization. Yeast 6, 311-318.

Poolman, B. \& Konings, W.N. (1988) Relation of growth of Streptococcus lactis and Streptococcus cremoris to amino acid transport. Journal of Bacteriology 170, 700-707.

Radler, F. (1990) Possible use of nisin in winemaking. II. Experiments to control lactic acid bacteria in the production of wine. American Journal of Enology and Viticulture 41, 7-11. 
Rehacek, J., Sozzi, T. \& Studer, P. (1982) Effect of water activity on the development of lactic acid bacteria and yeast utilized in the food industry. Milchwissenschaft 37, 151154.

Shah, N. \& Jelen, P. (1990) Survival of lactic acid bacteria and their lactases under acidic conditions. Journal of Food Science 55, 506-509.

Stamer, J.R. (1988) Lactic acid bacteria in fermented vegetables. Developments in Food Microbiology 3, 67-85.

Sugihara, T.F. (1985) Microbiology of breadmaking. In Microbiology of Fermented Foods. Vol. 1. ed. Wood, B.J.B. pp. 249-261. Barking: Elsevier Applied Science.

Ushio, K. \& NAKATA, Y. (1989) Isolation and characterization of mutants defective in salt tolerance in Zygosaccharomyces rouxii. Journal of Fermentation and Bioengineering $68,165-169$.
Vahvaselë̈, M., Hofman, M. \& Linko, P. (1990) Effect of oxygen on growth and lactose metabolism of Lactobacillus fermentum. In Proceedings of the 5th European Congress on Biotechnology, July 1990. Vol. 1. ed. Christiansen, C., Munck, L. \& Villadsen, J. pp. 298-301. Copenhagen: Munksgaard.

VAhVASelk $\ddot{A}$, M. \& Linko, P. (1990) Factors affecting lactic acid production and growth of Lactobacillus helveticus. In Processing and Quality of Foods. Volume 2: Food Biotechnology: Avenues to Healthy and Nutritious Products ed. Zeuthen, P., Cheftel, J.C., Eriksson, C., Gormley, T.R., Linko, P. \& Paulus, K. pp. 2.61-2.66. London: Elsevier Applied Science.

WARTH, A.D. (1988) Effect of benzoic acid on growth yield of yeasts differing in their resistance to preservatives. Applied and Environmental Microbiology 54, 2091-2095. 